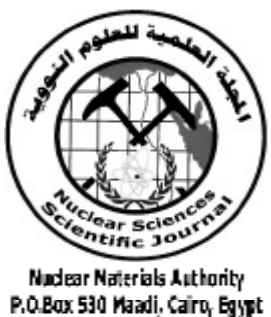

ISSN 2314-5609

Nuclear Sciences Scientific Journal

vol. 4, p 21- 36

2015

\title{
GEOLOGY, SPECTROMETRY AND EVALUATION OF THE RADIATION EXPOSURES AT EL GIDAMI-EL GARRA AREA, CENTRAL EASTERN DESERT, EGYPT
}

\author{
YASSIN A. ABDEL-RAZEK and MAHNMOUD A. M. MAHMOUD
}

Nuclear Materials Authority (NMA) P.O.Box, 530, Maadi, Cairo, Egypt

\begin{abstract}
El Gidami- El Garra area lies between latitudes $26^{\circ} 24^{\prime}-26^{\circ} 27^{\circ} \mathrm{N}$ and longitudes $33^{\circ} 20^{\circ}-33^{\circ} 29^{\prime} \mathrm{E}$, in the central Eastern Desert of Egypt, $3 \mathrm{~km}$ south of the midpoint of Qena-Safaga highway. The area is covered by younger granites intruded into amphibolites, and syn-tectonic granites. It represents one of the most promising uranium occurrences in the Eastern Desert. The main granitic types forming this pluton as defined from their mineral composition and textures comprise pegmatitic perthite granite, perthite granite and fluorite perthite granite.

Petrographically, these three types of younger granites are similar. The three types are perthitic in composition and medium to very coarse grained, even pegmatitic. Quartz, potash feldspar and plagioclase, with small amount of biotite and opaque minerals constitute the mineral assemblage in these types. Fluorite, zircon, allanite, titanite, apatite and monazite are accessory minerals. Chlorite, epidote, saussurite and muscovite are secondary constituents. In addition, there are some important radioactive minerals in the studied granites such as uranophane, xenotime and metamict zircon.

Locally, the estimated values of the external absorbed $\gamma$-radiation dose rate are $221.4 \pm 43.87,242 \pm 51.16$, $190.6 \pm 56.24$ and $294.9 \pm 39.81(\mathrm{nGy} / \mathrm{h})$ for the granitic rocks; fluorite perthite, Syn-tectonic, perthite and pegmatite perthite, respectively. These values are much higher than the worldwide average. Fortunately, neither public activities nor residential centers are recognized around the studied granites at El Gidami area.

The activity concentrations of the studied rocks are below the regulated values. As a result, all the occupational activities during surface exploration or transportation of the studied granitic rocks are excluded from the regulations and no need for any recommendations about the resulting effective doses.

Generally, the slabs of thickness of $4 \mathrm{~cm}$ from the different locations and granitic rock types exhibit an annual effective dose up to $2.41(\mathrm{mSv} / \mathrm{y})$. This value is below the action level and the studied granitic rock types may be used safely as decorative materials.

\section{INTRODUCTION}

The basement rocks in the Eastern Desert have been distinguished into three tectonolithologic domains: north, central and south Eastern Desert domains (Stern and Hedge, 1985; El Gaby et al., 1988). El Gidami - El Garra area lies in the northern part of the

central Eastern Desert domain. This domain comprises ophiolitic mélanges and associated rocks with subordinate molasse-type sediments of the Hammamat Formation and Dokhan volcanics. Widespread younger granites are present. Some of these granites are elongated in the NW direction. Large NW trending left
\end{abstract}


lateral strike-slip faults, similar to the Najd Fault System in the Arabian Shield are well developed in this domain (Shackleton et al., 1980; Stern and Hedge, 1985 and El Gaby et al., 1988).

The Egyptian granitic rocks are classified into two main groups; an older syn-tectonic calc-alkaline granite referred to as grey granites, and a younger or late- to post-tectonic granite series referred to as pink granites (El Ramly and Akaad, 1960; El-Shazly, 1964; El-Ramly, 1972; Sabet et al., 1972; El-Gaby, 1975 and Akaad and Noweir, 1980).

Late- to post-tectonic granites are distributed in El Gidami - El Garra area. The emplacement of these granites is structurally controlled by N-W trending faults, nearly parallel to the Red Sea (Abou Deif, 1985). These younger granites represent the last major magmatic event in the evolution of the crystalline basement of Egypt and belong to the Pan African plutonism. They are emplaced within a narrow time span at about 600-510 Ma age (Hashad, 1980; Hassan and Hashad, 1990).

\section{GEOLOGIC SETTING}

El Gidami- El Garra area lies between lat. $26^{\circ} 24^{\prime}-26^{\circ} 27^{\prime} \mathrm{N}$ and long. $33^{\circ} 20^{\prime}-33^{\circ} 29^{\prime} \mathrm{E}$, in the central Eastern Desert of Egypt, $3 \mathrm{~km}$ south of the midpoint of Qena-Safaga highway (Fig.1). The studied area was included in several previous studies such as: (Ammar, 1973; El-Gaby, 1975; Sabet et al., 1976; Nagy, 1977; Bakhit, 1978; Fullagar, 1980; Hashad, 1980; Greenberg, 1981; Habib, 1982; Attawiya, 1984; Abou Deif, 1985; Bakhit et al., 1985; Hussein et al., 1986; Hussein, 1987; Mohammed, 1988; Ahmed, 1991; Hussein et al., 1992; Abou Deif, 1992; El Mansi, 1993; Abu El Naga, 1994 and Oraby, 1999).

El Gidami-El Garra area is mainly covered by younger granites intruded into amphibolites, and syn-tectonic granites.

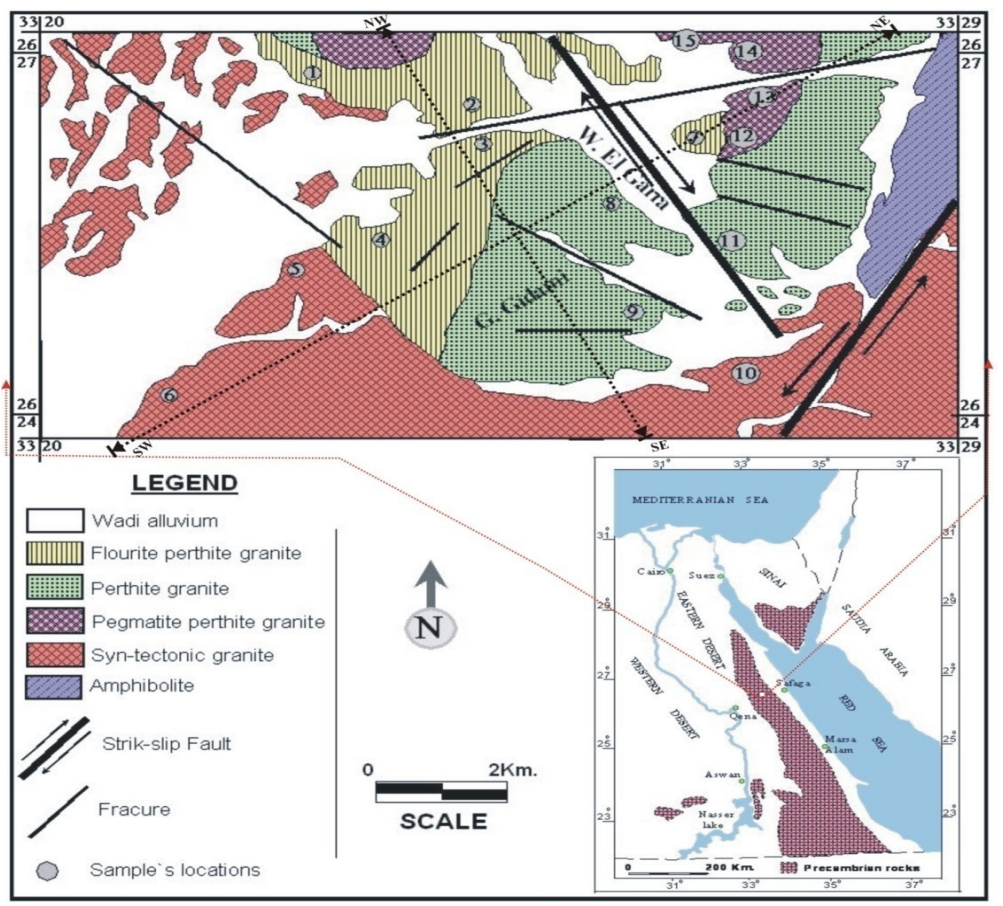

Fig. 1: Geologic map of El Gidami - El Garra studied area, Modified after Orabi, 1999 
Amphibolites comprise a narrow belt occupying the eastern parts of the studied area (Fig. 1). These rocks are medium to coarsegrained with dark green to green colors and has less well-developed foliation.

Syn-tectonic granites are represented by granodiorites which occupy the western and southern parts of the mapped area (Fig. 1). They are intruded by the younger granites and have gradational to sharp contact with the other rocks. They show exfoliation weathering and abundant xenoliths showing different degrees of assimilation. These granites are believed to have originated in the deep crustal levels and moved upwards to intrude the older rocks (Habib, 1982).

Younger granites are intruded into the amphibolites and syn-tectonic granitoids representing one of the most promising uranium occurrences in the Eastern Desert (Bakhit, 1978; Abou Deif, 1985; Abdallah, 1997 and Oraby, 1999). They are affected by alterations such as epidotization, kaolinization and hematitization. The main granitic rock types forming this pluton as defined from their mineral composition and textures are: -

Pegmatitic perthite granite occupies the northern part of the mapped area (Fig 1). It has low relief, pegmatitic texture and pink to pinkish white color. Inferred contacts with the fluorite perthite granite and perthite granite are found.

Perthite granite forms high relief making the distinct topographic feature of Gabal El Gidami and occupies the central and eastern parts of the mapped area (Fig. 1). It is massive, coarse to medium grained and pink to white in color and characterized by porphyritic margins. The rock is highly fractured and the joints are closely spaced.

Fluorite perthite granite occupies the central part of the studied area (Fig. 1). It has high relief, pink to white color and medium to coarse grain size. Fluorite perthite granite is highly sheared and shows mafic xenoliths.

\section{PETROGRAPHY}

Syntectonic granite (granodiorite) is coarse to medium grained, composed mainly of alkali feldspar, plagioclase, quartz, biotite and hornblende. Titanite, zircon and opaques are common as accessory minerals, while suassurite, chlorite and epidote are secondary minerals, (Fig. 2).

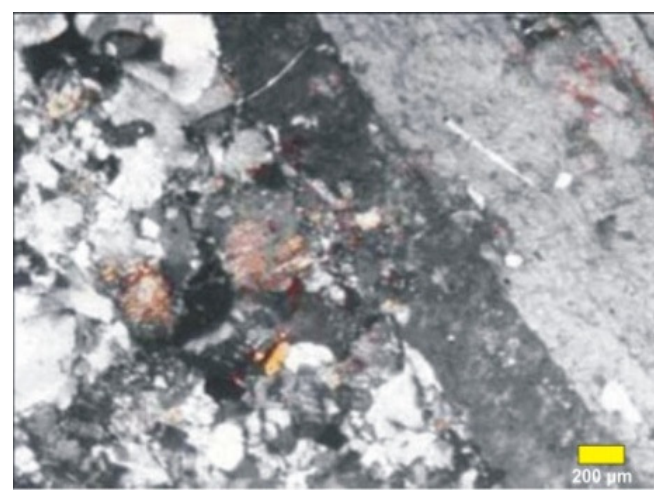

Fig.2: Altered plagioclase, hornblende and biotite in granodiorite. Notice zircon crystal,PPL

Plagioclase occurs as albite which has subhedral to anhedral crystals with varied degrees of alteration to saussurite. Complete saussuritization of plagioclase takes place, in some cases particularly when secondary quartz is observed, indicating later hydrothermal effect. Alkali feldspar occurs as orthoclase or microcline. Both are colorless and have low relief in plane light and may appear dusty due to alteration. Hornblende occurs as anhedral to subhedral and is partially altered to chlorite. Biotite occurs as flaky crystals with brown colors and is commonly altered to pale green chlorite. Quartz occurs in a variable abundance of grain size, where some of quartz is secondary in origin as alteration product filling the interstitial places between the plagioclase and the hornblende. Titanite, zircon and opaques occur in remarkably large crystals but in accessory amounts.

There is similarity of the petrographic characters among the three rock types of the younger granites at El Gidami- El Garra area. These rock types are perthitic in composi- 
tion and the grains are medium to very coarse grained, even pegmatitic. Quartz, potash feldspar and plagioclase, with a small amount of biotite and opaque minerals are the main mineral assemblage in these rock types, while fluorite, zircon, allanite, titanite, apatite and monazite are accessory minerals. Chlorite, epidote, sericite and muscovite are secondary minerals.

Quartz shows undulose extinction due to strain effect. Sometimes skeletal quartz is also observed (Fig. 3). Also, various shapes of myrmekites are observed along the grain boundary of plagioclases feldspar crystals (Fig. 4). Potash feldspars occur as microcline and orthoclase perthites of coarse string and patchy types (Fig. 5). Potash feldspar encloses primary plagioclase crystals and rounded quartz grains forming graphic like intergrowths (Fig. 4). Weak kaolinization is observed in some crystals. Plagioclase is represented by albite and occurs as euhedral crystals with variable sizes. Some plagioclase crystals are slightly to highly altered to saussurite and rarely epidotized in the core while the peripheries are still fresh indicating zonation. Some crystals of plagioclase showing bent twin lamella due to deformation (Fig. 7). Biotite occurs as corroded flakes of varying sizes with reddish brown, dark brown and green colors. It is often altered to chlorite and secondary muscovite or totally decomposed to iron oxides (Fig.8), and encloses zircon prisms with pleochroic halos (Fig.6). Zircon is found having brown and pale yellow shades. Fluorite has colorless to violet colors and occurs as secondary mineral associated with opaque patches enclosing radioactive minerals (Fig. 9). Allanite is present as large crystals, enclosed by biotite and quartz. Titanite is fairly pleochroic from pale brown to reddish brown (Fig. 10). Opaque minerals are always associated with biotite as irregular blebs or as subhedral crystals (Fig.10).

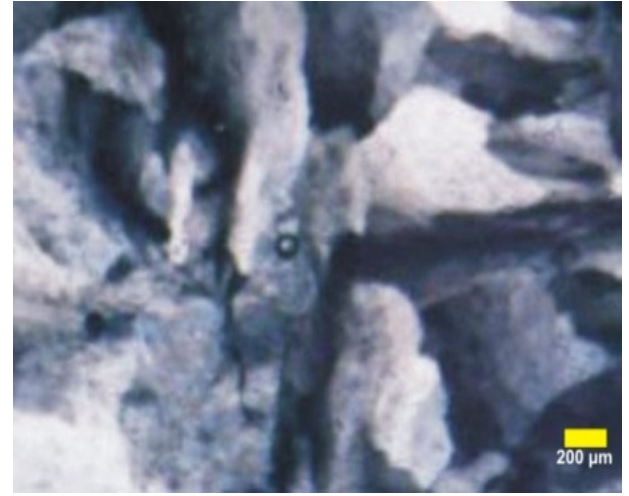

Fig. 3:Skeletal quartz grains, PPL

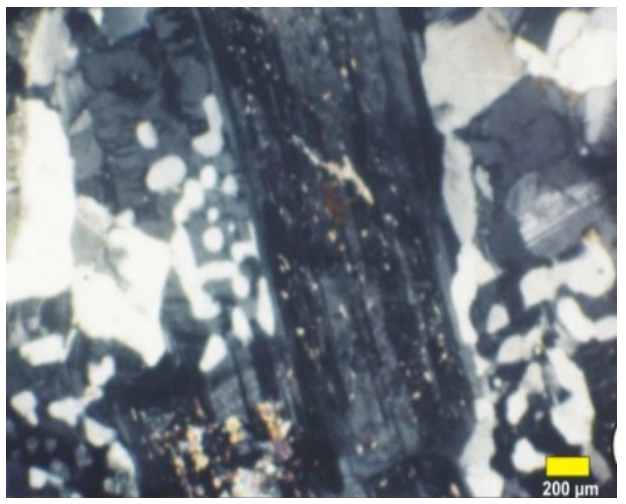

Fig. 4:Myrmekitic texture in pegmatite perthite granite, PPL

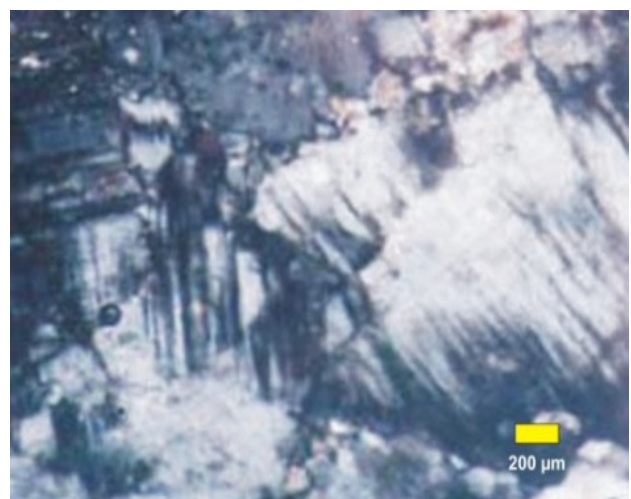

Fig. 5: Potash feldspar with string perthite, PPL 


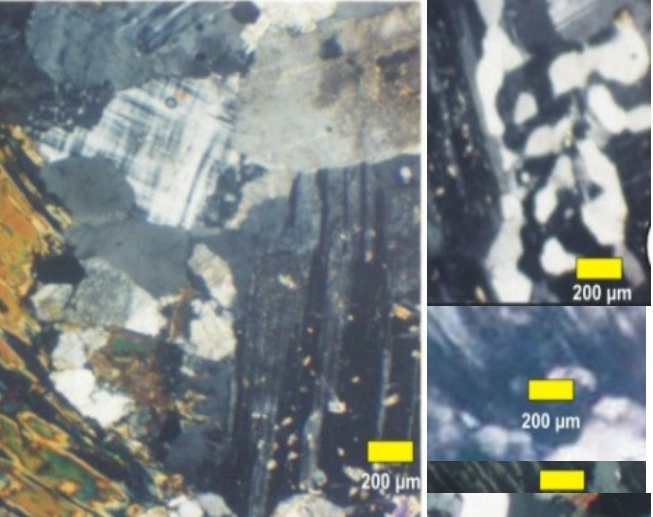

Fig. 6: Graphic intergrowth between feldspar and quartz. Notice biotite encloses zircon prisms with pleochroic halos, PPL

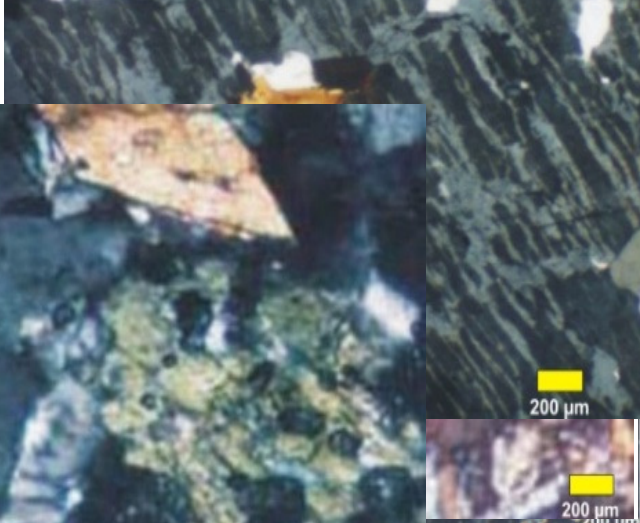

Fig. 7:Crystal of albite, Notice slightly bent lamellae, PPL

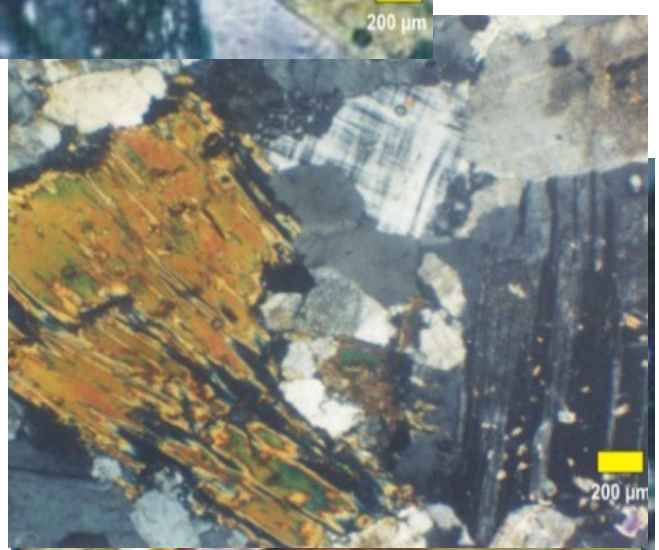

Fig. 8: Slightly chloritized of biotite ,PPL

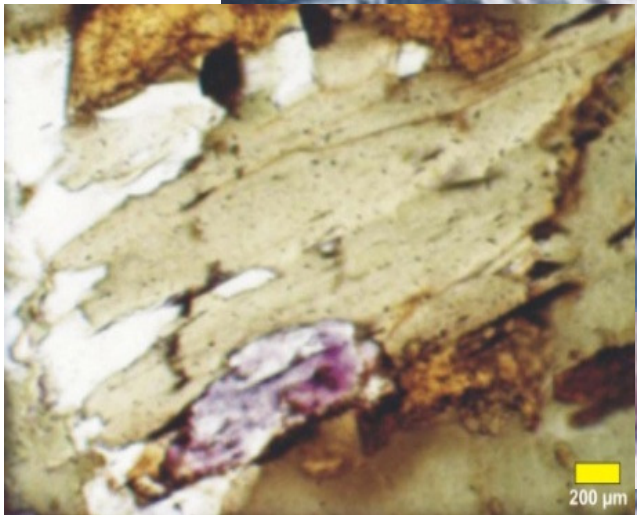

Fig. 9:Crystal of purple fluorite encloses radioactive material, PPL

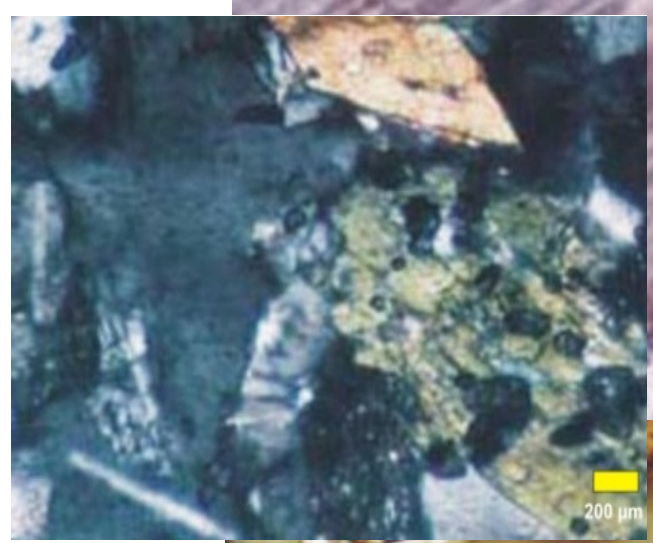

Fig. 10:Euhedral crystal of sphene mineral. Notice opaque minerals, PPL

\section{MINERALOGY}

Uranium mineralization was discovered by Bakhit (1978) in El-Gidami - El-Garra area,. The occurrence of uranium minerals is structurally controlled and along faults and fractures that are mainly filled with siliceous materials within a typical shear zone in the studied younger granites. The fracture and fault zones are controlled by NE-SW to E-W trends (Bakhit 1978 and Abu Deif 1985). The uranium mineralization is hosted in cryptocrystalline to amorphous jasperoid and black silica which were formed in more than one generation due to repeated rejuvenation of the 
structures (Abu Deif 1985).

Some mineralogical studies have been carried out on the studied granites, where the uranophane and zircon are the most important minerals.

\section{Uranophane}

Uranophane appears as a hair-like radiated shape (Fig.11) and it has earthy to waxy dull colors. It is occurs in the studied younger granites especially pegmatite perthite granite.

\section{Zircon}

Zircon appears as subhedral to euhedral crystals and varies in color from colorless, brown, grey, and yellow to red with variable sizes. The ESEM examination of zircon (Fig. 12) indicates evidences of chemical and crystallographic distortion.

\section{Xenotime}

Xenotime occurs as a prismatic bipyramidally ended euhedral crystals in all types of the studied younger granites and confirmed by SEM (Fig. 13).

\section{GAMMA-SPECTROMETRY}

Fifteen samples, each of $5 \mathrm{~kg}$ weight, were collected from different locations representing the granitic types; syn-tectonic granite, pegmatite perthite granite, perthite granite and

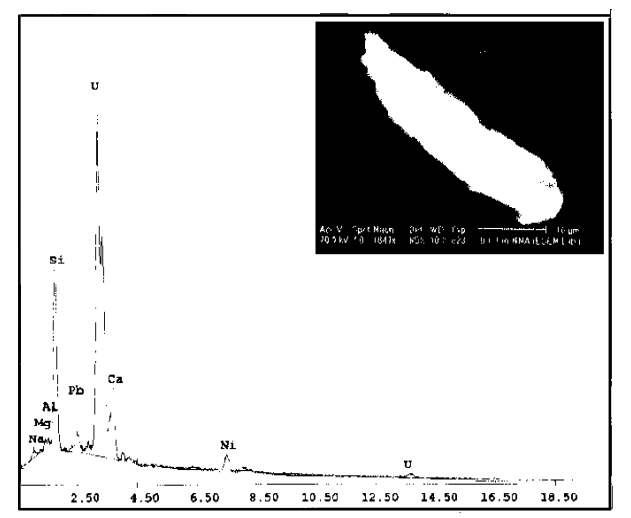

Fig. 11: ESEM photomicrograph of uranophane from pegmatite perthite granite

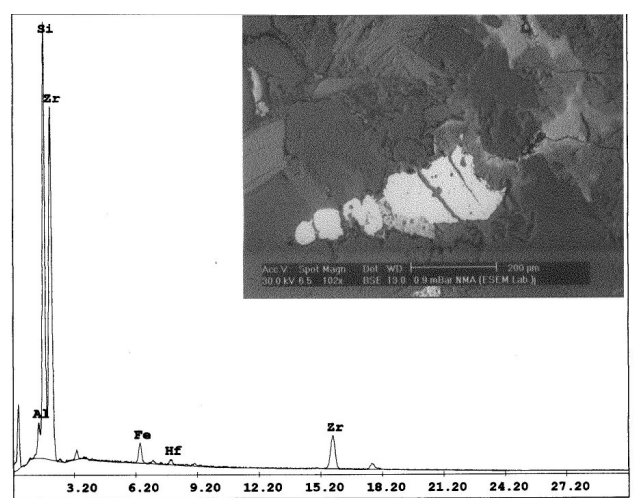

Fig. 12: ESEM photomicrograph of zircon from studied syntectonic granite

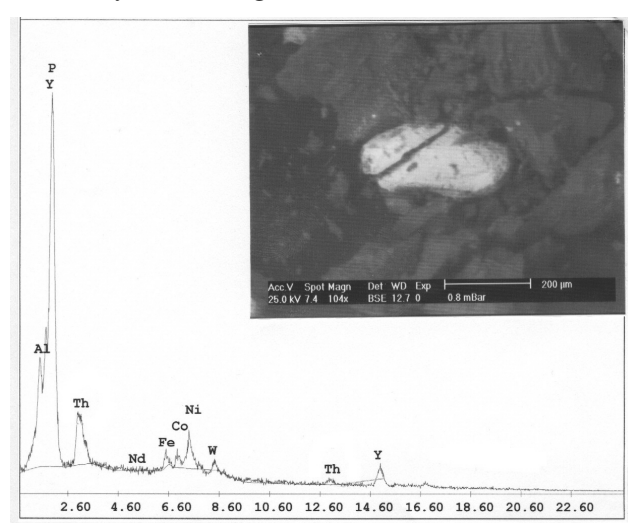

Fig. 13: ESEM photomicrograph of xenotime from studied younger granites

fluorite perthite granite, (Fig. 1).

The samples were washed in distillated water and dried in an oven at about $110^{\circ} \mathrm{C}$, they were crushed, homogenized, and sieved through a 200 mesh, which is the optimum size enriched in heavy minerals. Representative samples were transferred to polyethylene bottles of $350 \mathrm{~cm}^{3}$ volume. Each sample was sealed for 4 weeks to reach secular equilibrium where the rate of decay of the daughters becomes equal to that of the parent.

The samples were measured using a highresolution HPGe gamma-ray spectrometer system consisting of a p-type intrinsic germanium coaxial detector (model: GX3018) 
mounted vertically and coupled to $8 \mathrm{~K}$ multichannel analyser (Canberra). The detector was housed inside a lead shield to reduce the background of the system. The gamma-ray spectrometry analysis of the samples was carried out using an HPGe coaxial detector with a relative efficiency of $35 \%$ and a resolution of $1.78 \mathrm{keV}$ for the gamma emission of the $1333 \mathrm{keV}$ of ${ }^{60} \mathrm{Co}$. The gamma-ray spectra were analysed by means of the software associated with the detector. Since there was a low activity concentration in the samples, the counting time was long (18-24 h) so that the minimum detectable concentrations were sufficiently low as to be capable of measuring the low concentrations in the samples.

Measurements relied on the establishment of secular equilibrium in the samples, due to the much smaller lifetime of daughter radionuclides in the decay series of ${ }^{232} \mathrm{Th}$ and ${ }^{238} \mathrm{U}$. More specifically, the ${ }^{232} \mathrm{Th}$ concentration was determined from the average concentrations of ${ }^{212} \mathrm{~Pb}$ and ${ }^{228} \mathrm{Ac}$ in the samples, and that of ${ }^{238} \mathrm{U}$ was determined from the average concentrations of the ${ }^{214} \mathrm{~Pb}$ and ${ }^{214} \mathrm{Bi}$ decay products. Thus, an accurate measurement of ${ }^{232} \mathrm{Th}$ and ${ }^{238} \mathrm{U}$ concentrations was made, whereas a true measurement of ${ }^{40} \mathrm{~K}$ concentration was achieved.

The ${ }^{238} \mathrm{U}$ activity concentration was calculated from the mean value of gamma transitions obtained from the photo peaks of ${ }^{234} \mathrm{Th}$ $(63.28,92.37 \mathrm{keV})$. Each tabulated value for the ${ }^{232} \mathrm{Th}$ activity concentration was an average of the values obtained from the photo peaks of the ${ }^{212} \mathrm{~Pb}(238.63 \mathrm{keV}),{ }^{228} \mathrm{Ac}(209.25$, $338.32,911.2,968.97 \mathrm{keV})$ and ${ }^{208} \mathrm{Tl}(583.19$ $\mathrm{keV}$ ). The $1461 \mathrm{keV}$ gamma of ${ }^{40} \mathrm{~K}$ was used to determine the concentration of ${ }^{40} \mathrm{~K}$ in different samples.

\section{DISTRIBUTION OF U AND Th AT EL GIDAMI-EL GARRA PLUTON}

Darnley, (1982), defined the "uraniferous granites" as those containing at least twice the Clarke value (4ppm U), hence, they would contain 8ppm or more, regardless of the pres- ence of associated U-mineralization or not. Accordingly, the data in Table (1), suggest that the studied granites can be considered uraniferous granites, comprising the perthite granite (av. 15ppm U and 24ppm Th) representing the least differentiated granitic phase, followed by the fluorite perthite granitic phase (av. 20.4ppm U and 26.2ppm Th), the syn-tectonic granitic phase (av. 23ppm $U$ and $36.33 \mathrm{ppm} \mathrm{Th}$ ), and the pegmatite perthite granitic phase (av. 34.5ppm U and 2.75ppm Th), representing the most differentiated granitic phase. The last granitic phase does not show the expected increase in the Th content, but show some Th-depletion.

The relationships between $\mathrm{U}$, Th and $\mathrm{Th} / \mathrm{U}$ are shown in (Figs.14, 15 and 16). The variation in the $U$ and Th contents is shown in (Fig. 14), where the perthite, fluorite perthite and the syn-tectonic granitic phases exibit linear increasing relationship where as the

Table 1: The eU, eTh and $\mathrm{K}$ contents in the four studied granites at El Gidami-El Garra area

\begin{tabular}{|c|c|c|c|}
\hline $\begin{array}{l}\text { Location } \\
\text { No. } \\
\end{array}$ & $\begin{array}{r}\mathbf{e U} \\
(\mathbf{p p m})\end{array}$ & $\begin{array}{r}\mathbf{e T h} \\
\text { (ppm) }\end{array}$ & $\begin{array}{r}\mathbf{K} \\
(\%) \\
\end{array}$ \\
\hline \multicolumn{4}{|c|}{ Syn-tectonic granite } \\
\hline 5 & 16 & 26 & 3.6 \\
\hline 6 & 24 & 30 & 3.12 \\
\hline 10 & 29 & 23 & 3.9 \\
\hline Ave. & 23 & 26.33 & 3.54 \\
\hline \multicolumn{4}{|c|}{ Fluorite perthite granite } \\
\hline 1 & 22 & 23 & 2.7 \\
\hline 2 & 16 & 29 & 2.8 \\
\hline 3 & 21 & 31 & 3.2 \\
\hline 4 & 28 & 26 & 3.4 \\
\hline 7 & 15 & 22 & 3.5 \\
\hline Ave. & 20.4 & 26.2 & 3.12 \\
\hline \multicolumn{4}{|c|}{ Perthite granite } \\
\hline 8 & 11 & 24 & 3.5 \\
\hline 9 & 11 & 18 & 3.4 \\
\hline 11 & 23 & 30 & 3.7 \\
\hline Ave. & 15 & 24 & 3.53 \\
\hline \multicolumn{4}{|c|}{ Pegmatite perthite granite } \\
\hline 12 & 39 & 24 & 3.4 \\
\hline 13 & 38 & 23 & 3.16 \\
\hline 14 & 35 & 24 & 3.2 \\
\hline 15 & 26 & 20 & 3.2 \\
\hline Ave. & 34.5 & 22.75 & 3.24 \\
\hline All types & 23.6 & 24.87 & 3.32 \\
\hline
\end{tabular}


Th-depletion in the pegmatite perthite granite is documented. Figure (15) shows the variation between $\mathrm{Th} / \mathrm{U}$ ratios and $\mathrm{U}$ contents, exhibiting a decreasing linear relationship as expected. Figure (16) shows the variation between $\mathrm{Th} / \mathrm{U}$ ratios and Th contents, exhibiting the narrow variation in Th contents between $22.75 \mathrm{ppm}$ and $26.33 \mathrm{ppm}$, indicating that $\mathrm{Th}$ was not mobilized during igneous processes, while $\mathrm{U}$ mobilization is shown (Fig. 15). This might suggest that U-mobilization was affected by low temperature hydrothermal systems driven by heat produced locally in these anomalously radioactive plutons, (Fehn et al., 1978).

As mentioned above, many studies reported the contents of eU, eTh and $\mathrm{K}$ for $\mathrm{Al}$ Missikat-El Gidami-El Garra area. Table (2) summarizes the results of these studies

\section{EVALUATION OF RADIATION EXPOSURES}

In order to evaluate the radiation exposures arising in different situations from the studied granites, the contents of eU (ppm), eTh (ppm) and K (\%) should be converted into $(\mathrm{Bq} / \mathrm{kg})$. The activity concentration of a sample containing $1 \mathrm{ppm}$ by weight of ${ }^{238} \mathrm{U}$ is $12.35(\mathrm{~Bq} / \mathrm{kg}), 1 \mathrm{ppm}$ of ${ }^{232} \mathrm{Th}$ is $4.06(\mathrm{~Bq} /$ $\mathrm{kg}$ ) and $1 \%$ of ${ }^{40} \mathrm{~K}$ is $313(\mathrm{~Bq} / \mathrm{kg})$, (IAEA, 1989).

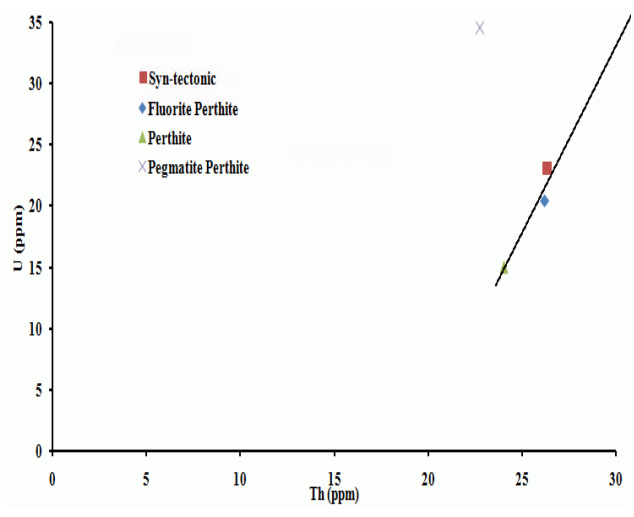

Fig.14: Variation of $\mathrm{U}$ and $\mathrm{Th}$ contents in the granitic rocks at El Gidami- El Garra pluton

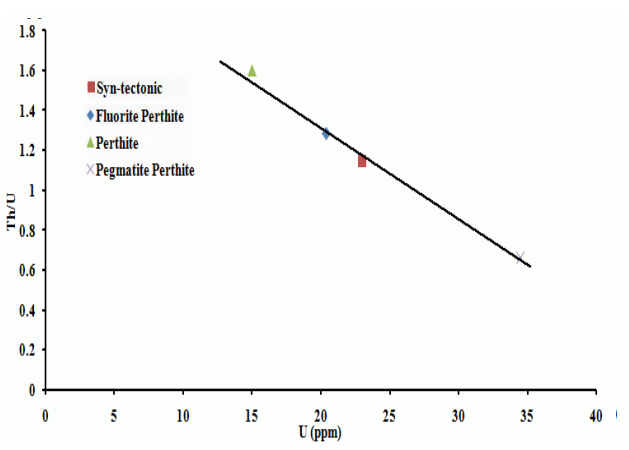

Fig. 15:Variation of the ration $\mathrm{Th} / \mathrm{U}$ and $\mathrm{U}$ content at El Gidami-El garra pluton

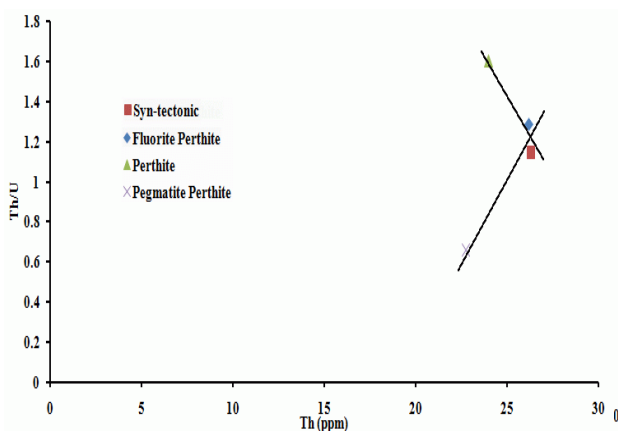

Fig. 16: Variation of the ration $\mathrm{Th} / \mathrm{U}$ and $\mathrm{Th}$ content at El Gidami-El Garra pluton

Table 2: The eU, eTh and $\mathrm{K}$ contents in the studied granites at Al Missikat-El Gidami-El Garra area

\begin{tabular}{|c|c|c|c|c|c|}
\hline Area & $\mathbf{N}$ & eU ppm & eTh ppm & K \% & Reference \\
\hline Al Missikat & 7 & $\begin{array}{r}13-35 \\
(19.86)^{*}\end{array}$ & $\begin{array}{r}14-27 \\
(20.86)\end{array}$ & $\begin{array}{r}2.54-3.55 \\
(3.1)\end{array}$ & $\begin{array}{r}\text { Hussain } \\
1987\end{array}$ \\
\hline albite & 7 & $(15.4)$ & (33.43) & $(3.34)$ & \\
\hline $\begin{array}{l}\text { Fluorite- } \\
\text { perthite }\end{array}$ & 25 & $(10.92)$ & (24.7) & (7.73) & \\
\hline perthite & 18 & (8.78) & (18.33) & (3.9) & Orabi \\
\hline $\begin{array}{l}\text { Pegmatite- } \\
\text { pertite }\end{array}$ & 11 & (10) & (21.81) & (3.75) & 1999 \\
\hline $\begin{array}{l}\text { Gidami-El } \\
\text { Garra }\end{array}$ & 61 & (10.5) & (22.97) & (3.49) & \\
\hline Older & 3 & $\begin{array}{r}2-8 \\
(2.94)\end{array}$ & $\begin{array}{r}3-19 \\
(9.23)\end{array}$ & $\begin{array}{r}2-4.5 \\
(2.18)\end{array}$ & \\
\hline Younger1 & 5 & $\begin{array}{r}4-20 \\
(9.31)\end{array}$ & $\begin{array}{r}11-32 \\
(17.94)\end{array}$ & $\begin{array}{l}2-5.3 \\
3.67)\end{array}$ & \\
\hline Younger2 & 5 & $\begin{array}{r}7-40 \\
(13.65)\end{array}$ & $\begin{array}{r}19-38 \\
(30.61)\end{array}$ & $\begin{array}{r}2.5-6 \\
(4.35)\end{array}$ & $\begin{array}{r}\text { Ibrahim } \\
2002\end{array}$ \\
\hline Younger3 & 3 & $\begin{array}{r}9-33 \\
(17.69)\end{array}$ & $\begin{array}{r}35-56 \\
(40.98)\end{array}$ & $\begin{array}{r}2.7-6.7 \\
(4.76)\end{array}$ & \\
\hline $\begin{array}{l}\text { Al Missika- } \\
\text { Gidami }\end{array}$ & 16 & $\begin{array}{c}0.1-51 \\
(7.21)\end{array}$ & $\begin{array}{r}2-65 \\
(16.92)\end{array}$ & $\begin{array}{r}0.1-8 \\
(2.68)\end{array}$ & \\
\hline Hole area & 84 & $\begin{array}{r}0.1-51 \\
(11.48)\end{array}$ & $\begin{array}{r}2-56 \\
(23.34)\end{array}$ & $\begin{array}{r}0.1-8 \\
(4.89)\end{array}$ & \\
\hline
\end{tabular}


Table (3) shows the activity concentration of the radionuclides; ${ }^{238} \mathrm{U},{ }^{232} \mathrm{Th}$ and ${ }^{40} \mathrm{~K}$ in the four different granitic rocks studied at El Gedami-El Garra pluton. From the table, it is clear that the activity concentration of the estimated radionuclides are much higher than the typical concentrations of these radionuclides in the earth crust of 32,40 and $400(\mathrm{~Bq} / \mathrm{kg})$ for ${ }^{238} \mathrm{U},{ }^{232} \mathrm{Th}$ and ${ }^{40} \mathrm{~K}$, respectively, (UNSCEAR, 2000). The activity concentration in the pegmatite perthite granite is clearly higher than its concentration in the other types of granites.

\section{Local Absorbed Dose Rate}

El Gidami-El Garra granitic rocks are aged to be Precambrian of about $600 \mathrm{Ma}$. Accordingly, this study assumes that all the decay

Table 3: Activity concentration of the radionuclides ${ }^{238} \mathrm{U},{ }^{232} \mathrm{Th}$ and ${ }^{40} \mathrm{~K}(\mathrm{~Bq} / \mathrm{kg})$, the defined total activity concentration $A_{\mathrm{T}}(\mathrm{Bq} / \mathrm{kg})$ and the absorbed dose rate $D(\mathrm{nGy} / \mathrm{h})$ at $1 \mathrm{~m}$ from the surface of four granitic rock types at El Gidami-El Garra area

\begin{tabular}{|c|c|c|c|c|c|}
\hline $\begin{array}{l}\text { Location } \\
\text { No. }\end{array}$ & $\begin{array}{r}{ }^{238} \mathrm{U} \\
(\mathrm{Bq} / \mathrm{kg})\end{array}$ & $\begin{array}{c}\begin{array}{c}232 \mathrm{Th} \\
(\mathrm{B} q / \mathrm{kg})\end{array} \\
\end{array}$ & $\begin{array}{r}{ }^{40} \mathrm{~K} \\
(\mathrm{~Bq} / \mathrm{kg})\end{array}$ & $\begin{array}{r}A_{\mathrm{T}} \\
(\mathrm{Bq} / \mathrm{kg})\end{array}$ & $\begin{array}{r}D \\
\text { (nGy/h) }\end{array}$ \\
\hline \multicolumn{6}{|c|}{ Syn-tectonic granite } \\
\hline 5 & 197.6 & 105.56 & 1126.8 & 415.8 & 202.0 \\
\hline 6 & 296.4 & 121.8 & 976.56 & 515.9 & 251.2 \\
\hline 10 & 358.15 & 93.38 & 1220.7 & 573.6 & 272.8 \\
\hline Average & 284.05 & 106.91 & 1108.0 & 501.8 & 242.0 \\
\hline SD & 80.98 & 14.26 & 123.15 & 79.8 & 51.16 \\
\hline \multicolumn{6}{|c|}{ Fluorite perthite granite } \\
\hline 1 & 271.7 & 93.38 & 845.1 & 449.6 & 217.2 \\
\hline 2 & 197.6 & 117.74 & 876.4 & 403.0 & 199 \\
\hline 3 & 259.35 & 125.86 & 1001.6 & 485.4 & 237.6 \\
\hline 4 & 345.8 & 105.56 & 1064.2 & 557.8 & 267.9 \\
\hline 7 & 185.25 & 89.32 & 1095.5 & 384.1 & 185.2 \\
\hline Average & 251.94 & 106.37 & 976.6 & 456.0 & 221.4 \\
\hline SD & 64.53 & 15.57 & 111.5 & 69.36 & 43.87 \\
\hline \multicolumn{6}{|c|}{ Perthite granite } \\
\hline 8 & 135.85 & 97.44 & 1095.5 & 342.8 & 167.3 \\
\hline 9 & 135.85 & 73.08 & 1064.2 & 315.4 & 151.3 \\
\hline 11 & 284.05 & 121.8 & 1158.1 & 521.7 & 253.1 \\
\hline Average & 185.25 & 97.44 & 1105.9 & 393.3 & 190.6 \\
\hline SD & 85.56 & 24.36 & 47.81 & 112.0 & 56.24 \\
\hline \multicolumn{6}{|c|}{ Pegmatite perthite granite } \\
\hline 12 & 481.7 & 97.44 & 1064.2 & 685.6 & 325.8 \\
\hline 13 & 469.3 & 93.38 & 989.1 & 661.6 & 314.5 \\
\hline 14 & 432.3 & 97.44 & 1001.6 & 629.9 & 300.3 \\
\hline 15 & 321.1 & 81.2 & 1001.6 & 502.5 & 239.2 \\
\hline Average & 426.1 & 92.37 & 1014.1 & 619.9 & 294.9 \\
\hline SD & 73.06 & 7.69 & 33.9 & 81.53 & 39.81 \\
\hline
\end{tabular}

products of ${ }^{238} \mathrm{U}$ are in radioactive equilibrium with their precursors. This mean that the activity concentration of ${ }^{238} \mathrm{U}(\mathrm{Bq} / \mathrm{kg})$ will replace that of ${ }^{226} \mathrm{Ra}$ wherever needed.

The absorbed dose rate in the air due to the gamma rays at $1 \mathrm{~m}$ from the surface of the granitic rocks are calculated using ${ }^{238} \mathrm{U},{ }^{232} \mathrm{Th}$ and ${ }^{40} \mathrm{~K}$ concentration values in these rocks. The conversion factor used to calculate the absorbed dose rates $D(\mathrm{nGy} / \mathrm{h})$ according to the relation, (UNSCEAR, 1988):

$$
D=0.427 A_{\mathrm{U}}+0.662 A_{\mathrm{Th}}+0.043 A_{\mathrm{K}}
$$

where $A_{\mathrm{U}}, A_{\mathrm{Th}}$ and $A_{\mathrm{K}}$ are the mean activities of ${ }^{238} \mathrm{U},{ }^{232} \mathrm{Th}$ and ${ }^{40} \mathrm{~K}$ in $(\mathrm{Bq} / \mathrm{kg})$, respectively.

In the above relation, it is assumed that all the decay products of ${ }^{238} \mathrm{U}$ and ${ }^{232} \mathrm{Th}$ are in radioactive equilibrium with their precursors. Table (4) represents the value of the absorbed dose rate $\mathrm{D}(\mathrm{nGy} / \mathrm{h})$ due to the contents of ${ }^{238} \mathrm{U},{ }^{232} \mathrm{Th}$ and ${ }^{40} \mathrm{~K}$ in the four granitic rock types at the studied area. The worldwide average values of $D$ range from 18-93 (nGy/h), (UNSCEAR, 2000).

The population weighted values of the absorbed dose rate in air outdoors from terrestrial gamma radiation estimated by the spectroscopic analysis of soil samples give an average of 60 (nGy/h), (UNSCEAR, 2000). This reveals that the averages of the absorbed dose rate in the air at $1 \mathrm{~m}$ above the surface of the studied granitic rocks are much higher than the worldwide average. Fortunately, neither public activities nor residential centers are recognized around the studied granitic rocks at El Gedami-El Garra area.

\section{Occupational Exposures During Exploration And Transportation Activities}

The International Commission on Radiological Protection (ICRP, 1990) recommended that the effective dose resulting from any occupational activities dealing with radioactive materials should not exceed $20 \mathrm{mSv} / \mathrm{y}$. How- 
ever, the International Atomic Energy Agency (IAEA, 2004) established a value of the activity concentration of a radioactive material below which it is usually unnecessary to regulate this material. For the radioactive materials of natural origin, this value is $10 \mathrm{kBq} / \mathrm{kg}$ for ${ }^{40} \mathrm{~K}$ and $1 \mathrm{kBq} / \mathrm{kg}$ for all other radionuclides of natural origin.

Accordingly, for a material containing a mixture of the radionuclides; ${ }^{238} \mathrm{U},{ }^{232} \mathrm{Th}$ and ${ }^{40} \mathrm{~K}$, the total activity concentration of this material is calculated as follows:

$A_{\mathrm{T}}=A_{\mathrm{U}}+A_{\mathrm{Th}}+0.1 A_{\mathrm{k}}(\mathrm{Bq} / \mathrm{kg})$

where $A_{\mathrm{U}}, A_{\mathrm{Th}}$ and $A_{\mathrm{K}}$ are the mean activities of ${ }^{238} \mathrm{U},{ }^{232} \mathrm{Th}$ and ${ }^{40} \mathrm{~K}$ in $(\mathrm{Bq} / \mathrm{kg})$, respectively.

From Table (3), it is clear that the values of $A_{\mathrm{T}}$ of the studied granitic rocks at all locations and the average values of $A_{\mathrm{T}}$ for each granitic rock type are below the declared value for a radioactive material to be regulated. As a result, all the occupational activities during surface exploration or transportation of the studied granitic rock types are excluded from the regulations and no need for any recommendations about the resulting effective doses.

\section{Public Exposures Due to Granitic Rocks as Decorative Materials}

The studied granitic rock types are considered uranium-bearing natural materials, but it is always possible to find uranium-rich rocks in these different types used by public as building materials. Construction materials are sources of airborne radioactivity and external radiation from the decay series of uranium in buildings.

\section{External Exposures}

Assuming that the absorbed dose rate $D$ at $1 \mathrm{~m}$ from the surface of the studied rocks estimated by equation (1) is due to the $\gamma$-rays emitted from the outer $10 \mathrm{~cm}$ layer of the rock, the absorbed dose rate $D_{\mathrm{t}}(\mathrm{nGy} / \mathrm{h})$ at $1 \mathrm{~m}$ from the surface of a granitic slab of thickness; $2 \mathrm{~cm}$, $3 \mathrm{~cm}$ or $4 \mathrm{~cm}$ is calculated as follows:
$D_{2 \mathrm{~cm}}=D / 5, D_{3 \mathrm{~cm}}=3 D / 10$ or $D_{4 \mathrm{~cm}}=2 D / 5 \quad(\mathrm{nG} / \mathrm{h})$

Table (4) represents the absorbed dose rated $D(\mathrm{nGy} / \mathrm{h})$ at $1 \mathrm{~m}$ from the surface of a granitic slab of thickness $2 \mathrm{~cm}, 3 \mathrm{~cm}$ and $4 \mathrm{~cm}$. From this Table, the average values of $D$ $(\mathrm{nGy} / \mathrm{h})$ for the $4 \mathrm{~cm}$ slabs from all the studied granitic rocks exceed the worldwide average of $60(\mathrm{nG} / \mathrm{h})$. The annual indoor effective dose for the public members using slabs of the studied granitic rock types as decorative materials is calculated as follows;

$$
\begin{aligned}
& E_{\mathrm{ex}}=D_{\mathrm{t}}\left(\mathrm{nGyh}^{-1}\right) \times 1.4 \times 8760 \mathrm{~h} \times 0.8 \times 0.7 \times 10^{-6} \\
& (\mathrm{mSV} / \mathrm{y})
\end{aligned}
$$

where $\mathrm{t}=2 \mathrm{~cm}, 3 \mathrm{~cm}$ and $4 \mathrm{~cm}$.

Table (4) represents the annual effective dose $E_{\mathrm{ex}}(\mathrm{mSv} / \mathrm{y})$ due the external exposure to the gamma rays emitted from a slab of different studied granitic rock types. The worldwide average of the external indoor effective dose is reported to have a value of $0.41(\mathrm{mSv} / \mathrm{y})$, (UNSCEAR, 2000). From the table, it is clear that the average values of $E_{\mathrm{ex}}(\mathrm{mSv} / \mathrm{y})$ for the $4 \mathrm{~cm}$ slabs from all types of granite exceed the worldwide average. Also, the data of $E_{\mathrm{ex}}$ show that the $3 \mathrm{~cm}$ slab of the syn-tectonic, perthite and fluorite perthite granites do agree with that of world average within one standard deviation. The $E_{\mathrm{ex}}$ value for the pegmatite perthite granite is much higher.

\section{Radon Flux From The Decorative Materials}

Radon flux $\left({ }^{222} \mathrm{Rn}\right)$ from the decorative materials is of interest since the short-lived decay products of radon are the greatest contributors to the lung dose of inhaled radionuclides (ICRP, 1993). Even though radon inlet into houses is a complex process involving decorative materials, soil, gas, water, and weatherrelated factors, ${ }^{226} \mathrm{Ra}$ in construction materials may be in some cases the predominant source. Much of the radon is released from the radium trapped in the mineral grains in building materials.

In building materials with high radium levels, the radon exhalation may become of ma- 
Table 4: Absorbed dose rate $D_{\mathrm{t}}(\mathrm{nGy} / \mathrm{h})$ at $1 \mathrm{~m}$ from the surface of a slap of granitic rock types at El Gidami-El Garra area and the relevant annual external effective dose $E_{\mathrm{Ex}}(\mathrm{mSv} / \mathrm{y})$. Radon flux $\mathrm{J}_{\mathrm{s}}\left(\mathrm{Bq} \mathrm{m}^{-2}\right.$ $\mathrm{s}^{-1}$ ) from a granitic slab into a reference house is represented

\begin{tabular}{|c|c|c|c|c|c|c|c|c|c|}
\hline \multirow{2}{*}{$\begin{array}{l}\text { Location } \\
\text { No. }\end{array}$} & \multicolumn{5}{|c|}{$2 \mathrm{~cm}$} & \multicolumn{2}{|l|}{$3 \mathrm{~cm}$} & \multicolumn{2}{|r|}{$4 \mathrm{~cm}$} \\
\hline & $\begin{array}{c}D \\
(n G y / h)\end{array}$ & $\begin{array}{c}\begin{array}{c}\boldsymbol{E}_{\mathbf{E x}} \\
(\mathbf{m S v} / \mathbf{y})\end{array} \\
\end{array}$ & $\begin{array}{c}\mathbf{J}_{\mathbf{s}} \\
\left(\mathbf{B q} \mathbf{m}^{-2} \mathbf{s}^{-1}\right) \\
\end{array}$ & $\begin{array}{c}D \\
(\mathbf{n G y} / h)\end{array}$ & $\begin{array}{c}\boldsymbol{E}_{\mathbf{E x}} \\
(\mathbf{m S v} / \mathbf{y}) \\
\end{array}$ & $\begin{array}{r}\mathbf{J}_{\mathbf{s}_{2}} \\
\left(\mathbf{B q} \mathbf{m}^{-2} \mathbf{s}^{-1}\right)\end{array}$ & $\begin{array}{c}D \\
(\mathrm{nGy} / \mathrm{h}) \\
\end{array}$ & $\begin{array}{c}\begin{array}{c}\boldsymbol{E}_{\mathbf{E x}} \\
(\mathbf{m S v} / \mathbf{y})\end{array} \\
\end{array}$ & $\begin{array}{c}\mathbf{J}_{\mathbf{s}} \\
\left(\mathbf{B q} \mathbf{m}^{-2} \mathbf{s}^{-1}\right)\end{array}$ \\
\hline \multicolumn{10}{|c|}{ Syn-tectonic granite } \\
\hline 5 & 40.40 & 0.28 & 0.0005 & 60.60 & 0.42 & 0.0007 & 80.8 & 0.55 & 0.0011 \\
\hline 6 & 50.24 & 0.35 & 0.0007 & 75.36 & 0.52 & 0.0010 & 100.5 & 0.69 & 0.0017 \\
\hline 10 & 54.56 & 0.37 & 0.0009 & 81.84 & 0.56 & 0.0013 & 109.1 & 0.75 & 0.0021 \\
\hline Ave. & 48.40 & 0.33 & 0.0007 & 72.60 & 0.50 & 0.0010 & 96.8 & 0.66 & 0.0016 \\
\hline SD & 7.26 & 0.05 & 0.0002 & 10.89 & 0.07 & 0.0003 & 14.51 & 0.10 & 0.0005 \\
\hline \multicolumn{10}{|c|}{ Fluorite perthite granite } \\
\hline 1 & 43.44 & 0.30 & 0.0013 & 65.16 & 0.45 & 0.0019 & 86.88 & 0.60 & 0.0031 \\
\hline 2 & 39.80 & 0.27 & 0.0010 & 59.70 & 0.41 & 0.0014 & 79.6 & 0.55 & 0.0023 \\
\hline 3 & 47.52 & 0.33 & 0.0013 & 71.28 & 0.49 & 0.0018 & 95.04 & 0.65 & 0.0030 \\
\hline 4 & $\mathbf{5 3 . 5 8}$ & 0.37 & 0.0017 & 80.37 & 0.55 & 0.0024 & 107.2 & 0.74 & 0.0040 \\
\hline 7 & 37.04 & 0.25 & 0.0009 & 55.56 & 0.38 & 0.0013 & 74.08 & 0.51 & 0.0021 \\
\hline Ave. & 44.28 & 0.30 & 0.0012 & 66.41 & 0.46 & 0.0018 & 88.55 & 0.61 & 0.0029 \\
\hline SD & 6.52 & 0.04 & 0.0003 & 9.78 & 0.07 & 0.0005 & 13.05 & 0.09 & 0.0007 \\
\hline \multicolumn{10}{|c|}{ Perthite granite } \\
\hline 8 & 33.46 & 0.23 & 0.0007 & 50.19 & 0.34 & 0.0010 & 66.92 & 0.46 & 0.0016 \\
\hline 9 & 30.26 & 0.21 & 0.0007 & 45.39 & 0.31 & 0.0010 & 60.52 & 0.42 & 0.0016 \\
\hline 11 & 50.62 & 0.35 & 0.0014 & 75.93 & 0.52 & 0.0020 & 101.2 & 0.70 & 0.0033 \\
\hline Ave. & 38.11 & 0.26 & 0.0009 & 57.17 & 0.39 & 0.0013 & 76.23 & 0.52 & 0.0021 \\
\hline SD & 10.95 & 0.08 & 0.0004 & 16.42 & 0.11 & 0.0006 & 21.90 & 0.15 & 0.0010 \\
\hline \multicolumn{10}{|c|}{ Pegmatite perthite granite } \\
\hline 12 & 65.16 & 0.45 & 0.0024 & 97.74 & 0.67 & 0.0034 & 130.3 & 0.90 & 0.0056 \\
\hline 13 & 62.90 & 0.43 & 0.0023 & 94.35 & 0.65 & 0.0033 & 125.8 & 0.86 & 0.0054 \\
\hline 14 & 60.06 & 0.41 & 0.0021 & 90.09 & 0.62 & 0.0031 & 120.12 & 0.82 & 0.0050 \\
\hline 15 & 47.84 & 0.33 & 0.0016 & 71.76 & 0.49 & 0.0023 & 95.68 & 0.66 & 0.0037 \\
\hline Ave. & 58.99 & 0.41 & 0.0021 & 88.49 & 0.61 & $\mathbf{0 . 0 0 3 0}$ & 118.0 & 0.81 & 0.0049 \\
\hline SD & 7.72 & 0.05 & 0.0004 & 11.58 & 0.08 & 0.0005 & 15.44 & 0.11 & 0.0008 \\
\hline
\end{tabular}

jor importance (Rizzo et al., 2001). Over the and $\mathrm{L}=6.8(\mathrm{~cm})$, to obtain the average values years, radon exhalation from building materi- of 0.023 for the emanation coefficient (f) for als has been the subject of many studies (Al- older granites, 0.046 for younger granites. TaJarallah, 2001., Al-Jarallah et al., 2001., Chen ble (4) represents the radon flux for the slaps et al., 2010., Ngachin et al., 2008., O’Brien et from the granitic rock types at different locaal., 1998, and Saad et al., 2010). Radon flux tions at El Gidami-El Garra area.

from a slab of thickness $t(\mathrm{~m})$ into the surrounding air is calculated using the equation, (UNSCEAR, 2000):

\section{Indoor Radon Concentration In a Reference House And The Resulting Effective Dose}

$\mathrm{J}=A_{\mathrm{U}} \lambda_{\mathrm{Rn}} \mathrm{f} \rho \operatorname{Ltanh}(\mathrm{t} / \mathrm{L})\left(\mathrm{Bqm}^{-2} \mathrm{~s}^{-1}\right)$ Where: $\mathrm{J}_{\mathrm{s}}=$ Radon flux from the decorative slab, $\left(\mathrm{Bq} \mathrm{m}^{-2} \mathrm{~s}^{-1}\right)$, on The Atomic Radiation (UNSCEAR, 2000) $\mathrm{A}_{\mathrm{U}}=$ Activity concentration of ${ }^{238} \mathrm{U},(\mathrm{Bq} / \mathrm{kg}), \lambda_{\mathrm{Rn}}=$ decay con- proposed a reference house which encloses stant of ${ }^{222} \mathrm{Rn}, \mathrm{s}^{-1}, \rho=$ density of the rock, $\mathrm{kg} / \mathrm{m}^{3}, \mathrm{f}=$ emanation an air volume of $250 \mathrm{~m}^{3}$ and a summation of coefficient, $\mathrm{t}=$ thickness of the decorative slab, $2 \mathrm{~cm}, 3 \mathrm{~cm}, 4 \mathrm{~cm}, \mathrm{~L}$ walls and floors area of $450 \mathrm{~m}^{2}$. Indoor radon $=$ diffusion length, $\mathrm{m}$. concentration in spaces other than tunnels is estimated using the formula:

Abdel-Razek (1997) studied the granitic

rocks at Al Missikat - El Aradiya area. He $\mathrm{C}_{\mathrm{Rn}}=\left(\mathrm{J}_{\mathrm{s}} \mathrm{XS} \mathrm{B}_{\mathrm{B}} / \mathrm{V}\right) / \lambda_{\mathrm{v}}+\mathrm{C}_{\text {out }}\left(\mathrm{Bq} / \mathrm{m}^{3}\right)$ used the rock parameters; $\rho=2600\left(\mathrm{~kg} / \mathrm{m}^{3}\right)$ 
Where: $\mathrm{C}_{\mathrm{B}}$ is the indoor radon activity concentration in a reference house $\left(\mathrm{Bq} \mathrm{m}^{-3}\right), \mathrm{J}_{\mathrm{s}}$ : is the flux density of radon from a building element $\left(\mathrm{Bq} \mathrm{m}^{-2} \mathrm{~h}^{-1}\right), \mathrm{S}_{\mathrm{B}}$ : is the emanating surface area $\left(450 \mathrm{~m}^{2}\right), \mathrm{V}$ : is the volume of the reference house $\left(250 \mathrm{~m}^{3}\right), \lambda_{\mathrm{v}}$ : is the ventilation rate chosen at $\left(1 \mathrm{~h}^{-1}\right), \mathrm{C}_{\text {out }}$ : is the worldwide average of the outdoor radon activity concentration, $4\left(\mathrm{Bqm}^{-3}\right)$, (Abdel-Razek et al., 2013).

The reported indoor radon concentration in Egypt has an average value $9\left(\mathrm{~Bq} / \mathrm{m}^{3}\right)$ with a maximum value of $24\left(\mathrm{~Bq} / \mathrm{m}^{3}\right)$, (Kenawy and Morsy, 1991, UNSCEAR, 2000). Table (5) shows the expected indoor radon concentration $\left(\mathrm{C}_{\mathrm{Rn}}\right)$ as a result of the decorative slabs from different granitic rock types of El Gidami-El Garra area. From this Table, the value of radon concentration due to a $4 \mathrm{~cm}$ slab from some locations of pegmatite perthite granite extends the maximum reported value in Egypt to reach $40\left(\mathrm{~Bq} / \mathrm{m}^{3}\right)$. The slabs from other granitic rock types exhibit radon concentrations which are below the reported average concentration. Generally, the higher values of $\mathrm{C}_{\mathrm{Rn}}$ as a result of the studied granitic slaps are within the worldwide range of 30-40 $\left(\mathrm{Bq} / \mathrm{m}^{3}\right),(\mathrm{UN}-$ SCEAR, 2000).
For the concentrations of radon, the equilibrium factor of 0.6 indoors with an occupancy factor of 0.8 , the annual effective doses $(\mathrm{mSv} / \mathrm{y})$ are derived from the following equations, (UNSCEAR, 2000);

$\left.E_{\mathrm{Rn}}=\mathrm{C}_{\mathrm{Rn}}\left(\mathrm{Bqm}^{-3}\right) \mathrm{x} 0.6 \mathrm{x} 8760 \mathrm{hx} 0.8 \mathrm{x} 9 \mathrm{nSv}(\mathrm{Bqhm})^{-3}\right)^{-1}(\mathrm{mSv} / \mathrm{y})$

Table (5) shows the annual effective doses due to the inhalation of radon in the homes using wall slabs from the granitic rock types at El Gidami-El Garra area. From this Table, except of the $4 \mathrm{~cm}$ slap of pegmatite perthite granite, all the values of the average annual effective doses received by the public members due to the inhalation of radon gas when they use the different granitic rocks from at El Gidami-El Garra area as wall slabs show $E_{\mathrm{Rn}}$ that are below the estimated worldwide average value of $1(\mathrm{mSv} / \mathrm{y})$. However, the annual effective doses due to radon gas emanating from a slap of thickness $4 \mathrm{~cm}$ from the pegmatite perthite granite is still below the action limit of 3 (mSv/y), (ICRP, 1993).

Table (5): Indoor radon concentration $\left(\mathrm{Bq} / \mathrm{m}^{3}\right)$, the relevant annual internal effective dose $E_{\mathrm{Rn}}(\mathrm{mSv} / \mathrm{y})$ and the total annual effective $E_{\mathrm{T}}(\mathrm{mSv} / \mathrm{y})$ due to a slap of granitic rock types at El Gidami-El Garra area

\begin{tabular}{|c|c|c|c|c|c|c|c|c|c|}
\hline \multirow[b]{2}{*}{$\begin{array}{l}\text { Location } \\
\text { No. }\end{array}$} & \multicolumn{4}{|c|}{$2 \mathrm{~cm}$} & \multicolumn{3}{|c|}{$3 \mathrm{~cm}$. } & \multicolumn{2}{|r|}{$4 \mathrm{~cm}$} \\
\hline & $\begin{array}{c}\begin{array}{c}\mathbf{C}_{\mathbf{R n}} \\
\left(\mathbf{B q} / \mathbf{m}^{3}\right)\end{array} \\
\end{array}$ & $\begin{array}{r}E_{\mathrm{Rn}} \\
(\mathrm{mSv} / \mathrm{y})\end{array}$ & $\begin{array}{r}\boldsymbol{E}_{\mathbf{T}} \\
(\mathrm{mSv} / \mathbf{y})\end{array}$ & $\begin{array}{r}\begin{array}{c}\mathbf{C}_{\mathbf{R n}} \\
\left(\mathrm{Bq} / \mathbf{m}^{3}\right)\end{array} \\
\end{array}$ & $\begin{array}{r}E_{\mathrm{Rn}} \\
(\mathrm{mSv} / \mathrm{y})\end{array}$ & $\begin{array}{r}E_{\mathbf{T}} \\
(\mathrm{mSv} / \mathrm{y})\end{array}$ & $\begin{array}{r}\begin{array}{r}\mathbf{C}_{\mathbf{R n}} \\
\left(\mathrm{Bq} / \mathbf{m}^{3}\right)^{3}\end{array} \\
\end{array}$ & $\begin{array}{c}\boldsymbol{E}_{\mathrm{Rn}} \\
(\mathrm{mSv} / \mathrm{y})\end{array}$ & $\begin{array}{r}E_{\mathbf{T}} \\
(\mathrm{mSv} / \mathbf{y})\end{array}$ \\
\hline \multicolumn{10}{|c|}{ Syn-tectonic granite } \\
\hline 5 & 7.13 & 0.27 & 0.55 & 8.53 & $\mathbf{0 . 3 2}$ & 0.74 & 11.38 & 0.43 & 0.99 \\
\hline 6 & 8.69 & 0.33 & 0.67 & 10.80 & 0.41 & 0.93 & 15.07 & 0.57 & 1.26 \\
\hline 10 & 9.67 & 0.37 & 0.74 & 12.22 & 0.46 & 1.02 & 17.38 & 0.66 & 1.41 \\
\hline Ave. & 8.49 & $\mathbf{0 . 3 2}$ & 0.65 & 10.52 & 0.40 & 0.90 & 14.61 & 0.55 & 1.22 \\
\hline SD & 1.28 & 0.05 & 0.10 & 1.86 & 0.07 & 0.14 & 3.02 & 0.11 & 0.21 \\
\hline \multicolumn{10}{|c|}{ Fluorite perthite granite } \\
\hline $\mathbf{1}$ & 12.60 & 0.48 & 0.78 & 16.47 & 0.62 & 1.07 & 24.30 & 0.92 & 1.52 \\
\hline 2 & 10.25 & 0.39 & 0.66 & 13.07 & 0.49 & 0.90 & 18.76 & 0.71 & 1.26 \\
\hline 3 & 12.21 & 0.46 & 0.79 & 15.90 & 0.60 & 1.09 & 23.37 & 0.88 & 1.54 \\
\hline 4 & 14.94 & 0.57 & 0.93 & 19.87 & 0.75 & 1.30 & 29.83 & 1.13 & 1.86 \\
\hline 7 & 9.86 & $\mathbf{0 . 3 7}$ & 0.63 & 12.50 & 0.47 & 0.85 & 17.84 & 0.68 & 1.18 \\
\hline Ave. & 11.97 & 0.45 & 0.76 & 15.56 & 0.59 & 1.04 & 22.82 & 0.86 & 1.47 \\
\hline SD & 2.04 & 0.08 & 0.12 & 2.96 & 0.11 & 0.18 & 4.82 & 0.18 & 0.27 \\
\hline \multicolumn{10}{|c|}{ Perthite granite } \\
\hline 8 & 8.30 & o.31 & 0.54 & 10.23 & 0.39 & 0.73 & 14.15 & 0.54 & 0.99 \\
\hline 9 & 8.30 & 0.31 & 0.52 & 10.23 & 0.39 & 0.70 & 14.15 & 0.54 & 0.95 \\
\hline 11 & 12.99 & 0.49 & 0.84 & 17.03 & 0.64 & 1.17 & 25.22 & 0.95 & 1.65 \\
\hline Ave. & 9.86 & 0.37 & 0.63 & 12.50 & 0.47 & 0.87 & 17.84 & 0.68 & 1.20 \\
\hline SD & 2.71 & o.10 & 0.18 & 3.93 & o.15 & 0.26 & 6.39 & 0.24 & 0.39 \\
\hline \multicolumn{10}{|c|}{ Pegmatite perthite granite } \\
\hline 12 & 19.24 & 0.73 & 1.18 & 26.10 & 0.99 & 1.66 & 39.98 & $\mathbf{1 . 5 1}$ & 2.41 \\
\hline 13 & 18.85 & 0.71 & 1.15 & 25.53 & 0.97 & 1.61 & 39.06 & 1.48 & 2.34 \\
\hline 14 & 17.68 & 0.67 & 1.08 & 23.84 & 0.90 & 1.52 & 36.29 & 1.37 & 2.20 \\
\hline 15 & 14.16 & 0.54 & 0.86 & 18.73 & 0.71 & 1.20 & 27.99 & 1.06 & 1.72 \\
\hline Ave. & 17.48 & 0.66 & 1.07 & 23.55 & 0.89 & 1.50 & 35.83 & 1.36 & 2.17 \\
\hline SD & 2.31 & 0.09 & 0.14 & 3.35 & 0.13 & 0.21 & 5.46 & 0.21 & 0.31 \\
\hline
\end{tabular}


The total annual effective dose $\mathrm{E}_{\mathrm{T}}$ is the sum of the annual external effective dose $\mathrm{E}_{\text {ex }}$ and the annual internal dose due the inhalation of radon $\mathrm{E}_{\mathrm{Rn}}$ :

$$
E_{\mathrm{T}}=E_{\mathrm{ex}}+E_{\mathrm{Rn}} \quad(\mathrm{mSv} / \mathrm{y})
$$

From the information reported above, the worldwide average value of the total annual effective dose due to gamma rays and radon gas is $1.41(\mathrm{mSv} / \mathrm{y})$. From Table (5), within one standard deviation, only the average value of $E_{\mathrm{T}}(\mathrm{mSv} / \mathrm{y})$ for the $4 \mathrm{~cm}$ slabs due to pegmatite perthite granite exceeds the worldwide average. Generally, the higher values of $E_{\mathrm{T}}$ are associated with the $4 \mathrm{~cm}$ slab from pegmatite perthite granite, fortunately, these values are below the mentioned action level. Accordingly, the studied granitic rock types may be used safely as decorative materials.

\section{CONCLUSION}

There is a similarity in petrographic characters of three types of younger granites at El Gidami- El Garra area. They are all perthitic in composition, and medium to very coarse grained, even pegmatitic. There are some important radioactive minerals in the studied granites such as uranophane, xenotime and metamict zircon which are responsible for radioactivity in the studied area. The values of the local absorbed doses are much higher than the worldwide average. Fortunately, neither public activities nor residential centers are recognized around the studied granites at El Gidami-El Garra area. Surface exploration or transportation activities of the studied granitic rocks are excluded from the regulations and no need for any recommendations about the resulting effective doses. Generally, the slabs of thicknesses of $4 \mathrm{~cm}$ from the different locations and granitic rock types cause an annual effective dose up to $2.41(\mathrm{mSv} / \mathrm{y})$. This value is below the action level and the studied granitic rock types may be used safely as decorative materials.

\section{Acknowledgements}

The authors are acknowledged to the staff of the Environmental Radioactivity Measurements Laboratory (ERML), physics department, Faculty of Science, University of south valley, Qena, for their sincere cooperation to accomplish the spectrometric data.

\section{REFERENCES}

Abdallah,S. M., 1997. Subsurface geologic studies of Gebel El-Missikat uranium occurrence, Central Eastern Desert, Egypt. M. Sc Thesis,Fac. Sci., Cairo, Univ., 157p.

Abdel-Razek, Y. A., 1997. Measurements of Radon Gas Concentrations and Radon Progeny in Uranium Exploration Galleries. M.Sc. Thesis, Fac. Sci., Ain Shams Univ., 137p.

Abdel-Razek, Y.A.; Said, A.F., and Hassan, S.F., 2013. Outdoor exposures at Baltim area. Arab J. Nucl. Sci \&. Aplicat., 45, 411-418.

Abou Deif, A., 1985. Geology of uranium mineralization in El - Missikat area, Qena -Safaga road, Eastern Desert, Egypt. M. Sc. Thesis, Fac. Sci.,Al -Azhar Univ. Cairo. 103p.

Abou Deif, A., 1992. The relation between the uranium mineralization and tectonics in some Pan African granites, west of Safaga Eastern Desert, Egypt. Ph. D. Thesis, Fac. Sci., Assiut Univ., 218 p.

Abu El Naga, H. S., 1994. Relation between geology and Gamma- ray spectrometry of ElMissikat radioactive prospect, Central Eastern Desert, Egypt. M. Sc. Thesis, Fac. Sci., Ain Shams, Univ., 157p.

Ahmed, N.A.,1991. Comparative study of the accessory heavy minerals in some radioactive rocks of G. El -Missikat and G. El - Erediya, Eastern Desert, Egypt and their alluvial deposits. M.Sc. Thesis,Fac. Sci., Cairo Univ., Egypt, $163 \mathrm{p}$.

Al-Jarallah, M., 2001. Radon exhalation from granite used in Saudi Arabia. J. Environ. Radioac- 
tivity, 53, 91-98.

Al-Jarallah, M.I.; Abu-Jarad, F., and Fazal-urRehman, 2001. Determination of radon exhalation rates from tiles using active and passive techniques. Radiat. Meas., 34, 491-495.

Akaad, M.K., and Noweir, M.F., 1980. Geology and lithostratigraphy of the Arabian Desert orogenic belt of Egypt between latitudes $25^{\circ} 30^{\prime}$ and $26^{\circ} 30^{\prime} \mathrm{N}$, Jaddah, King Abdulaziz Univ., Inst. Apple. Geol. Bull., 3\& 4, 127-135.

Ammar, A. A., 1973. Application of aerial radiometry to the study of the geology of Wadi El Gidami, Eastern Desert, Egypt (with aeromagnetic application). Ph. D. Thesis,Fac. Sci., Cairo Univ, 424p.

Attawiya, M.Y., 1984.On the geochemistry and genesis of the uranium mineralization of ElMissikat area, Egypt. Ann. Geol. Surv. Egypt, $13,1-13$.

Bakhit, F.S., 1978. Geology and radioactive mineralization of G. El Missikat area Eastern Desert, Egypt. Ph.D. Thesis, Fac. Sci., Ain Shams Univ., Cairo, Egypt.

Bakhit, F.S.; Assaf, H. A., and Abou Deif, A., 1985. Correlation study on the geology and radioactvity of surface and subsurface working at ElMissikat area, Central Eastern Desert, Egypt, Min. Geol., 35, 345-354.

Chen, J.; Rahman, N.M., and Atiya, I.A., 2010. Radon exhalation from building materials for decorative use. J. Envir. Radio., 101(4), 317-322.

Darnley, A.G., 1982. Hot Granites: Some general remarks. In: Uranium in granites ( Maurice, Y.T, Ed.). Proc. workshop held in Ottawa, Geol. Surv. Canada, paper 81-23, 2-10.

El-Gaby, S., 1975. Petrochemistry and geochemistry of some granites from Egypt. Neus $\mathrm{Jb}$. Mineral, Abh., 124, 174-189.

El-Gaby, S.; List. F. K., and Tehrany, R., 1988. Geology, evolution and metallogenesis of the Pan African belt of Egypt. In: The Pan African Belt of Northeast African and Adjacent
Areas; Tectonic Evolution and Economic Aspects of Late Proterozoic Orogen (El-Gaby and Greiling,Eds.). Friedr Vieweg and Sohn, Braunschweing/Wiesbaden, 17-67.

El Mansi, M.M.M., 1993. Petrology, Radioactivity and Mineralizations of Abu-Gerida-El Eradiya area, Eastern Desert, Egypt. M.Sc. Thesis,Fac. Sci., Cairo Univ., 223p.

El- Ramly, M. F., 1972. A new geological map for the basement rocks in the Eastern and Southwestern Desert of Egypt, Scale 1: 100,000. Ann. Geol. Surv. Egypt, 2, 1-18.

El-Ramly, M. F., and Akaad, M. K., 1960. The basement complex in the Central Eastern Desert of Egypt, between lat. $24^{\circ} 30^{\prime}$ and $25^{\circ} 40^{\prime}$. Geo. Surv. Egypt, Paper No. 8, 33.

El-Shazly, E. M., 1964. On the classification of the Precambrian and other rocks of magmatic affiliation in Egypt, U.A.R., Report presented in section 10, Int., Geol., Congr., India, 88 -99.

Fehn, V.; Cathles, L.M. and Holand, H.D., 1978. Hydrothermal convection and ranium deposits in abprimally radioactive plutons. Econ. Geol.,73, 1556-1566.

Fullagar, P. D., 1980. Pan African age granites of northeastern Africa: new or reworked sialic materials, In: The geology of Libya (Salem, M. J. and Busrewit, M.T. , Eds). Academic press, III, 1051-1058.

Greenberg, J. K., 1981. Characteristics and origin of Egyptian younger granites; Summary. Geol. Soc. Am. Bu. 92, Pt.1, 242-232.

Habib, M. E., 1982. Landsat investigation of mineralized granites in the area between Gabals El-Urf and El-Erediya due west of Safaga, Egypt, $8^{\text {th }}$ Int. Data, LARS/ Purdue Univ.,West Lafayette, U.S.A., 441- 446.

Hashad. A. H., 1980. Present status of geochronological data on the Egyptian Basement Complex. Bull. Inst. Appl. Geol., King Abdulaziz. Univ., Jeddah, 3(3), 31-46.

Hassan, M. A., and Hashad, A. H., 1990. Precam- 
brian of Egypt. In: Geology of Egypt (Said, R., Ed.). Bulkema publ., Netherlands, 73.

Hussein, A. H. A., 1987. Geochemistry of granitic rocks and uranium mineralization in El-Missikat - El-Erediya area, SW Safaga Eastern Desert, Egypt. Ph.D. Thesis, Fac. Sci.,Cairo Univ., Egypt, 254.

Hussein, H.A.; Hassan, M.A.; El-Tahir, M.A., And Abou Deif, A., 1986. Uranium bearing siliceous veins in younger granites, Eastern desert, Egypt, Report of the working Group on Uranium Geology, IAEA. Vienna, TECDOC, 143-157.

Hussein, H. A.; El-Tahir, M. A., and Abou-Deif, A., 1992. Uranium exploration and through exploratory mining work, south Qena-Safaga midway, Eastern Desert, Egypt. $3^{\text {rd }}$ Min., Metallurgy Conf., Cairo Univ., 1, 92-105.

International Atomic Energy Agency (IAEA), 1989. Construction and use of calibration facilities for radiometric field equipment. IAEA Technical Reports Series No. 309, Vienna.

International Atomic Energy Agency (IAEA), 2004. Application Of The Concepts Of Exclusion, Exemption And Clearance. IAEA-Safety Standards Series, RS-G-1.7, Vienna.

ICRP, 1990. Recommendations of the International Commission on Radiological Protection. Ann. ICRP 21(1-3). ICRP Publication 60. Pergamon Press, Oxford.

ICRP, 1993. Against radon-222 at home and at work. International Commission on Radiological Protection. Protection. Ann. ICRP 22(2). ICRP Publication 65. Pergamon Press, Oxford.

Kenawy, M.A., and Morsy, A.A., 1991. Measurements of environmental radon-222 concentration in indoor and outdoors in Egypt. Nucl. Tracks Radiat. Meas., 19, 343-345.

Mohammed, N. A.,1988. Mineralogical and petrographical characteristics of some alteration products related to U-mineralization in El-Missikat-El-Erediya areas Eastern Desert, Egypt,
M. Sc. Thesis,Fac. Sci., Cairo Univ, 110.

Nagy, R.M., 1977. Geochemistry of the Raba El Garra pluton, Egypt. Ph. D Thesis, Rice Univ., U.S.A., 73.

Ngachin, M.; Garavaglia, M.; Giovani, C.; Nourreddine, A.; Kwato Njock, MG. ; Scruzzi, E., and Lagos, L., 2008. ${ }^{226} \mathrm{Ra},{ }^{232} \mathrm{Th}$ and ${ }^{40} \mathrm{~K}$ contents and radon exhalation rate from materials used for construction and decoration in Cameroon. J. Radiol. Prot., 28, 369-378.

O'Brien, R.S.; Aral, H., and Peggie, J.R., 1998, Radon exhalation rates and gamma doses from ceramic tiles. Health Phys., 75, 630-639.

Oraby, F. M., 1999. Geologic, petrographic and geochemical studies of uraniferous granitoids in El Garra - El Gidami area, Central Eastern Desert, Egypt. Ph.D. Thesis, Fac. Sci.,South Valley Univ., Egypt, 151.

Rizzo, S.; Brai, M.; Bellia, S., and Hauser, S., 2001, Gamma activity and geochemical features of building materials: estimation of gamma dose rate and indoor radon levels in Sicily. Appl. Radiat. Isot., 55(2), 259-265.

Saad, A.F.; Abdalla, Y.K.; Hussein, N.A.,and Elyaseery, I.S., 2010, Radon exhalation rate from building materials used on the Garyounis University Campus, Benghazi. Libya. Turkish J. Eng. Env. Sci., 34, 67-74.

Sabet, A.H.; Bessonenka, V.V., and Bykove, B. A., 1976. The intrusive complexes of the central Eastern Desert of Egypt. Ann. Geol. Surv. Egypt, VIII, 53-73.

Sabet, A.H.; El Gaby. S., and Zalata, A. A., 1972. Geology of the basement rock in the northern parts of El-Shayib and Safaga sheets, Eastern Desert, Egypt. Ann. Geol. Surv. Egypt, II, 111128.

Shackleton, R.M.; Ries, A.C.; Graham, R.H., and Fitches, W.R., 1980. Late Precambrian Ophiolitic Melange in the Eastern Desert of Egypt. Nature, 285, 472-474.

Stern, R. J., and Hedge, C. D., 1985. Geochrono- 
logic and isotopic constraints on Late Precambrian crustal evolution in the Central Eastern Desert of Egypt. Am. J. sci. 285, 97-127.

UNSCESR, 1988. Exposures from natural sources of radiation. United Nations Scientific Commit- tee on the Effects of Atomic Radiation, Report to the General Assembly, Annex A, 49-134.

UNSCEAR, 2000. Exposures from natural sources of radiation. United Nations Scientific Committee on the Effects of Atomic Radiation, Report to the General Assembly, Annex A, 83-156.

\section{الجيولوجيا والقياس الطيفي وتقييم التعرضات الإشعاعية بمنطقة الجدامى ـ الجرة، وسط الصحراء

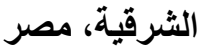 \\ يس عبد العظيم محمد عبد الرازق و محمود أحمد محمد محمود}

تقع منطقة الجدامى_ الجرة وسط الصحر اء الثرقية في منتصف المسافة بطريق قناـ سفاجا الأسفلتى ثم جنوبا

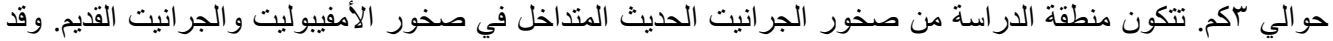

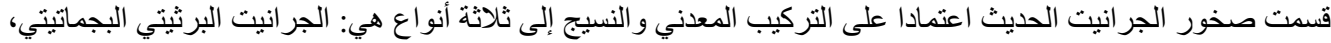

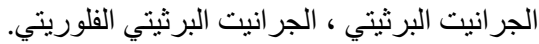

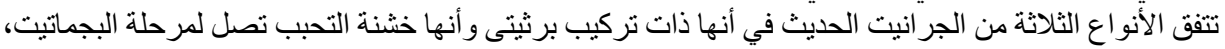

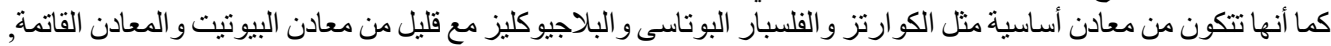

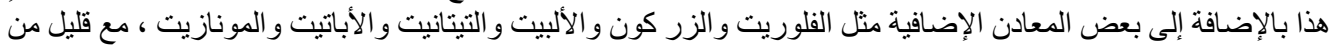

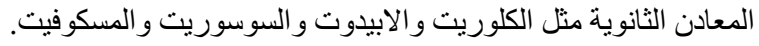

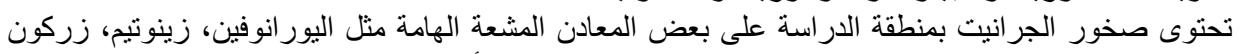

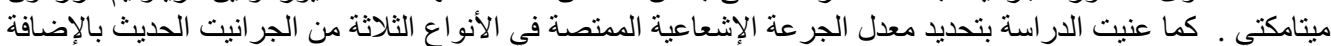

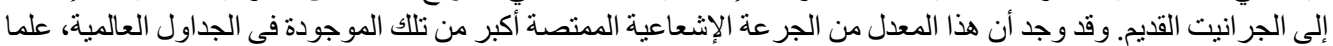

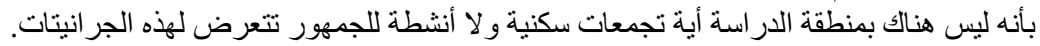
وقد تبين من الدراسة أنه يمكن استخدام جرانيتات منطقة الجدامىـ الجرة كجلادات للحوائط وتبليط الأرضيات لأرضيات 